\title{
A HISTORY OF THE DES MOINES POST OFFICE
}

\author{
By IldDa M. HAMmer
}

FOREWORD

The writer obtained a complete list of the postmasters from Mr. Huffman; a statement of the receipts of the post office since 1880, and of the valrious Congressional appropriations concerning the post office through the kindness of our representative, Hon. C. C. Dowell; some later figures and data were supplied through the courtesy of Mr. John Ryan, assistant postmaster; and several years ago Major W. H. Fleming was kind enough to help very materially in the search for data, and to add some very interesting personal reminiscences. To all of these, the writer wishes to express her appreciation.

Few persons who see or transact busincss in the present postoffice building on the river front, ever stop to think of what the beginnings of the Des Moines post office may have been, or of the rapid growth which has attended it.

The post office was established at Fort Des Moines in 1845, and was known as Raceoon River ${ }^{1}$ until June 1, 1846, when the name Fort Des Moines was given it. Josiah Smart, who was the Indian interpreter for the military authorities at the Fort, was appointed as the first postmaster, but declined to accept the appointment, and Dr. Thomas K. Brooks filled the place March 2, 1846, as the first regular postmaster. Dr. Brooks had his office in the old Indian Agency House, which was situated where the Tuttle stone packing house was in 1909, in South Des Moines. Later Dr. Brooks removed the office to his own home in Thomas Addition, on Court Avenue. At the close of the year (1846) Dr. Brooks resigned, and Phineas M. Casady succeeded him in office on December $31,1846 .{ }^{1 \text { a }}$

Mr. Casady moved the post office to his own law office on Second Street and the Rock Island tracks, where Green's Foundry used to be. The mail was not very heavy at that time, for it is said of Mr. Casady that he used to carry it in his hat, and distribute it to the parties to whom it was directed, "lifting the post office from his head" in order to find the letters."

1U. S. Official Register, 1847.

1aFortèr, Will. Annals of Polk County and the City of Des Moines, p. 709-10. 2 Turrill, H. B. Historical Reminiscences of the City of Des Moines, p.23. 
In this connection it is interesting to note that at the semicentennial of Polk County in 1896, Judge Casady conducted a reproduction of distribution as it had been done a half century before. Letters were distributed to the following persons, among others : Hoyt Sherman, Col. Griffiths, George C. Tidrick, E. R. Clapp, Isaac Cooper, Byron Rice, and P. M. Casady. Back postage was due on many of the letters. Isaac Cooper owed twenty-five cents, as was common in the early days. We are told that on this occasion the letters were brought to Judge Casady in a pair of saddle bags by Isaac Warfel, who carried mail into Des Moines in 1846.

Robert L. 'Tidrick, Mr. Casady's law partner, succeeded him as postmaster October 26, 1848, and the post office remained where it was in the law office, until the appointment of Hoyt Sherman June 26, 1849. Mr. Sherman, with his own funds, built a frame building to be used exclusively as a post office on West Second and Vine streets. ${ }^{3}$

Up until this time, postage rates were five cents for each half ounce or fraction thereof, for not over three hundred miles; for a greater distance, the rate was ten cents. Envelopes had not been introduced, and it was a part of one's education to learn how to fold a letter so that one could find a suitable place on which to write the address. It was not necessary at this time, either, to prepay the postage. This change occurred during the term of Wesley Redhead, who was appointed February 11, 1853; at about the same time, the rate was reduced to three cents per half ounce.

During Mr. Redhead's term of office, in 1857, three and onehalf tons of mail were received weekly; about 38,000 letters were received and dispatched every quarter; the post office contained 576 boxes and 80 drawers. Mr. Redhead kept the office in the Sherman Block, on Third and Court Avenue. ${ }^{4}$ In 1857 the name of the office was changed to Des Moines.

John Teesdale suceeded Wesley Redhead May 6, 1861, and held office until April 17, 1867. The following schedule of postal arrangements was in effect during Mr. Teesdale's term:

3Hussey, Tacitus, Beginnings, p. 66; Des Moines Register and Leader, April $25,1909$.

4Turrill, 99. 
Eastern via Chicago \& Davenport arrives at 6 A. M. ${ }^{5}$

Eastern via Chicago and Davenport closes at 7 P. M.

Southern via Oskaloosa and Keokuk arrives at 9 A. M.

Southern via Oskaloosa and Keokuk closes at 2 P. M.

Western via Adel arrives at $4 \mathrm{P}$. M.

Western via Adel closes at 7 P. M.

Winterset arrives at $4 \mathrm{P} . \mathrm{M}$.

Winterset closes at 7 P. M.

Ft. Dodge except Sundays and Mondays arrives at 5 P. M.

Ft. Dodge except Fridays and Saturdays closes at 7 P. M.

Xenia Thursdays and Saturdays arrives at 6 P. M.

Xenia Mondays and Wednesdays closes at 7 P. M.

Boonesboro Tuesdays, Thursdays, and Saturdays arrives at 4 P. M.

Boonesboro Sundays, 'Tuesdays, and Saturdays, closes a.t 7 P. M.

Newark and Vandalia Tuesdays, Thursdays, and Saturdays, arrives at $6 \mathrm{P}$. M.

Newark and Vandalia Sundays, Tuesdays, and Thursdays. closes at 7 P. M.

Indianola (via Summerset) Mondays, Wednesdays, and Fridays, arrives at $12 \mathrm{M}$.

Indianola (via Summerset) Mondays, Wednesdays, and Fridays, closes at 1 P. M.

Indianola (via Hartford) Tuesdays, Thursdays, and Saturdays, arrives at $6 \mathrm{P}$. M.

Indianola (via Hartford) Mondays, Wednesdays and Fridays, closes at 7 P. M.

Nevada Tuesdays and Saturdays arrives at $6 \mathrm{P}$. M.

Nevada Sundays and Thursdays closes at 7 P. M.

New Jefferson Sundays arrives at 4 P. M.

New Jefferson Sundays and Wednesdays closes at 7 P. M.

No mails to connect with the Rail Roads depart on Saturdays.

No mails to connect from the Rail Roads arrive on Mondays.

Office opened, except Sunday, from 8 A. M. until $7 \frac{1}{2}$ P. M.

Office opened on Sundays from 9 to $10 \mathrm{~A}$. M.

J. Teesdale, P. M.

Des Moines, Iowa, Jan. 11, 1864.

5In this schedule we follow the exact wording and style used as appears in its publication in the Daily State Register (Des Molnes), January 17, 1864. 
Business had increased to quite an extent by 1867 , at the close of Mr. Teesdale's appointment. About 6,000 letters were received weekly for distribution, and the sale of postage stamps amounted to $\$ 12,000$ annually. During the year 1866 about $\$ 13,000$ of money orders had been paid, with as great an amount issued. ${ }^{6}$ The office contained over 1,000 boxes, and 125 drawers.

It was during Mr. Teesdale's term also that a congressional act of July 28, 1866, authorized and appropriated the sum of $\$ 15,000$ for a site, and an Act of March 2, 1867, the sum of $\$ 85,000$ for a building, to be used as a post office and court house. We now know this building as the "Old Federal Building."

Under Mr. Tichenor, who was appointed April 18, 1867, the post office was located in a frame building in the rear of the Sherman Block. In 1868 plans were announced for the proposed new building under the congressional acts above mentioned, and acts of July 20,1868, and of April 20, 1870, authorized respectively the sums of $\$ 89,008.00$ and $\$ 24,575.00$ for continuation. The building was only about half completed under this first contract, and during the appointment of James S. Clarkson (July 28, 1871-March 3, 1879) nothing additional was done. ${ }^{7}$

While John Beckwith, who succeeded Mr. Clarkson March 4, 1879 , was in office, two additional stories and a wing were put up, under authority of acts of August 7, 1883, July 7, 1884, March 3, 1885, and June 30,1886 , which authorized a total of $\$ 330,000$ for repairs and additional rooms. ${ }^{8}$

Col. Wm. H. Merritt assumed the duties of postmaster August 13, 1886. His appointment by President Cleveland was bitterly denounced in the Iowa State Register (Republican) "as a gross violation of the civil service laws on the part of President Cleveland." The editor asserted that he had no objection whatever to Col. Merritt as a man, and did not doubt but that he would serve as well as had his predecessor, Mr. Beckwith; but, he declared, he did object to the removal of Mr.

6Daily State Register (Des Moines), April 26, 1867.

7From data furnished by Hon. C. C. Dowell.

$8 I b i d$.

9I010a State Register (Des Molnes), August 13, 1886. 
Beckwith on no other grounds than that he was a Republican, while Col. Merritt was a Democrat. However, in spite of his politics, the postal business gradually increased under Col. Merritt's administration, as well as under that of Isaac Brandt, who took office June 30, 1890, and served until July 25, 1894.

As the close of Mr. Brandt's term drew near, a bitter contest was waged between two aspirants for the next appointment. Joseph Eiboeck, publisher of the Anzeiger, a German weekly, and acknowledged leader of the German Democrats of the state, and Edward H. Hunter were the two contestants. Mr. Hunter received the appointment, to the general dissatisfaction of Republicans, as expressed in the Iowa State Register. Mr. Hunter was accused of being a fearless "manipulator of machines and combines," while Mr. Eiboeck was lauded as an "upright and fearless fighter for the Democrats." 10 The editor goes on to say that this is not the first time that the administration has "duped" the German vote, of which Mr. Eiboeck is the honored representative, and that it is evident that Mr. Hunter did some clever manipulating and "wirepulling" in Washington.

Lewis Schooler was postmaster from September 18, 1898, to December 9, 1902. June 6, 1902, an act was passed providing a limit of $\$ 150,000$ for the site for a new post office, and February 18, 1904, during John McKay's term (December 10, 1902-March 18,1907$)$ an additional sum for site was appropriated. ${ }^{11}$

An Act of June 30, 1906, provided a limit of $\$ 500,000$ for building, which amount was appropriated in the acts of June 30, 1906, March 4, 1907, and March 4, 1909. The new building on the river front was completed during Joseph I. Myerly's incumbency (March 19, 1907-May 31, 1911) at a total cost of $\$ 488,016.67 .^{12}$

Lonis C. Kurtz was appointed postmaster June 1, 1911, and served in that capacity until June 30,1915 . During this time, the post-office business was constantly increasing, and new departments were added. The total receipts for the year preceding Mr. Kurtz's appointment were $\$ 784,538.82$; for the year 1914 they were $\$ 1,086,173.61$-almost fifty per cent increase.

10Iova State Register, July 24, 1894.

11 From data furnished by Hon. C. C. Dowell.

12 Ibid. 
In the same time the amount of newspapers handled increased from $12,960,968$ pounds a year to $16,662,262$ pounds-tribute to the publishing industry of Des Moines. The money order department showed a gain of from 77,022 orders, amounting to $\$ 684,408.65$, to 93,180 orders, amounting to $\$ 753,900.00$. During Mr. Kurtz's administration, the Postal Savings Bank was inaugurated, and between September 15, 1911, and June $30,1915,1,982$ accounts, with deposits totaling $\$ 269,198.00$ were opened. The Parcel Post System was inaugurated in Des Moines June 1, 1913, and at the close of Mr. Kurtz's term of office 10,000 parcels per day, on an average, were being dispatched, and 2,146 (average) pareels per day were being received.

July 1, 1915, George A. Huffman was appointed as Mr. Kurtz's successor, and served in that capacity until 1924. During that time, many ehanges were effected in the postal service, great strides were made in the efficiency with which that service was rendered, and postal receipts were almost. tripled. By 1924, the Des Moines post office was selling more stamps per capita than any other office in the United States; Des Moines had become the twenty-eighth among leading cities in the country in postal business; an average of forty-six tons of second class (periodical publications) matter was handled daily; and the Des Moines office had become the central accounting office for all third and fourth class post offices in Iowa, handling an annual pay roll of about four and one-half million dollars for Iowa rural carriers. ${ }^{13}$

As the end of Mr. Huffman's second term drew near, in 1924, three candidates appeared for his position-William C. Harbach, Irvin M. Lieser, and Z. C. Thornburg. The report of the civil service commission gave Mr. Harbach the highest rating, and for this reason Senator Cummins recommended him for the position, in spite of the opposition of the junior senator, Mr. Brookhart. Senator Brookhart warned his colleague that if Mr. Harbach's name were presented to the Senate, he would invoke the personal privilege rule, and trust to the Senate to sustain him. Mr. Brookhart's opposition to Mr. Harbach dated from the Polk County Republican Conven-

13 Des Moines Tribune, July 1, 1924. 
tion early that spring, when Mr. Harbach had opposed the nomination of Mr. Brookhart. ${ }^{14}$

President Coolidge sent Mr. Harbach's name to the Senate May 2, and the Senate in executive session May 19 sustained Senator Brookhart's objection. ${ }^{15}$ Senator Cummins later recommended Mr. Z. C. Thornburg, who had been given the second highest rating by the commission. The junior Senator had no objection to Mr. Thornburg, and the latter became postmaster July 1, 1924.

The Des Moines post office by this time was ranked in the $\$ 3,000,000$ class. Since $1922^{16}$ there had been talk of an addition to accommodate its expanding business. It was hoped that one of the changes made during Mr. Thornburg's term would be the enlargement of the post office to cover the entire ground owned by the government (the north half of the block between First and Second streets, and Walnut Street and Court Avenue). ${ }^{17}$

Mr. Thornburg lived less than a year after he was appointed, and on May 18, 1925, Edwin J. Frisk, the present postmaster, assumed his duties, although he did not receive formal appointment until the following year. ${ }^{18}$ Receipts continued to increase, until they amounted to $\$ 3,176,064.69$ for the fiscal year ending June $30,1926 .^{10}$ A movement was set on foot in December, 1925, to secure an appropriation for an addition to the post office. Agitation continued, but it was not until August 10,1930, as a result of a survey ordered by the Treasury Department, that postal department inspectors recommended the purchase of the south half of the block on which the present building stands. This property was owned by several different concerns-the Hubbel estate, the Bankers Life Company, the $\mathrm{H}$ and $\mathrm{H}$ Cleaner Company, Tone Brothers, and the Brown Camp Campany. March 4, 1931, a bill was approved appropriating $\$ 775,000$ for the site and building. ${ }^{20} \mathrm{Ne}-$ gotiations were begun, and an agreement was soon reached

\footnotetext{
${ }^{14}$ Des Moines Dally Capital, April 28, 1824.

15 Des Moines Register, May 20, 1024.

16 Des Moines Daily Capital, December 22, 1922.

17 Des Moines Tribune, July 1, 1924.

18 Des .Molnes Register, January 27, 1926.

10From flgures furnished by Mr. John Ryan, Assistant Postmaster.

20 U. S. Stat. at Large, 71st. Congress, Sess. III, Vol. 46, Pt. I, Ch. 522.
} 
with the Hubbell estate, the Bankers Life Company, and the $\mathrm{H}$ and $\mathrm{H}$ Cleaner Company. The government felt that the price asked by the Brown Camp Company, and Tone Brothers was too high, and on September 22, 1931, an order was issued for the condemnation of the property.

Federal Judge Charles A. Dewey appointed six Iowa men to serve as a condemnation jury. They were: Frank F. Everest, Council Bluffs ; L. A. Jester, Des Moines ; J. E. Espy, Ottumwa; W. A. Lawrenson, Des Moines; Anson Marston, Ames; George W. Graeser, Des Moines. George Warner, Newton, and Henry Negus, Iowa City, were alternates. ${ }^{21}$ The condemnation action was filed October 21, naming three defendants-Tone Brothers, Brown Camp Company, and C. C. Taft Company lessees of Brown Camp Company.

The report of the condemnation jury, filed December 3,1931 , allowed a total of $\$ 370,000$ for the purchase of the condemned property. This amount was divided as follows: Tone Brothers, $\$ 128,000$; Brown Camp Company, $\$ 180,000$; and C. C. Taft Company, $\$ 62,000 .{ }^{22}$ These figures proved to be acceptable to both the government and the owners of the land, and on February 5,1932 , payment was made by the government. ${ }^{23}$ The above figures, added to the $\$ 120,750$ agreed upon as the purchase price of the remainder of the half block, brought the total payment for site up to $\$ 490,750$, leaving $\$ 284,250$ of the appropriation $(\$ 775,000)$ to be used for building purposes.

Wetherell and Harrison, Architects, drew the plans for the proposed addition. For the present, these include an extension back of the present building, which, at some future date, will be joined to an extension on Court Avenue similar in size and architecture to the present structure. ${ }^{24}$ The building, when completed, will face the river front. It was expected that work would be begun in 1932 , but it was delayed. Bids are now being received by the government; September 6, 1933, is the last date on which they may be submitted. It is hoped that this fall will see the beginning of work.

Under Mr. Frisk's administration, many improvements have

21 Des Moines Register, October 22, 1931.

22Ibid., December 4, 1931.

23From data furnished by Mr. Jobn Ryan.

24 From the architect's drawings, through the courtesy of Mr. John Ryan. 
been made in the mail service available to Des Moines. Six named substations help to relieve the load of the central office. One of these, in Highland Park, erected in 1929, was - the first post office in Des Moines to have all steel equipment. In 1930 a substation was opened in the old Federal Building. Before that, a new station had been established on Grand Avenue, between Seventh and Eighth streets, and the University Place station had been housed in new and enlarged quarters. Courtesy boxes have been installed for the convenience of motorists. Miniature post offices have been established in the lobbies of several down town office buildings, where the mail is distributed by the postman and called for by the tenants, thereby saving the time formerly required for delivery to each office. The air mail service has been introduced, and has become an increasingly used facility.

In 1927, 440 persons were in the employ of the postal department in Des Moines. Thirty-six trucks were used to handle mail daily-eleven of them delivered and collected parcel post, and the others hauled mail between the post offices and the various railroad stations. In the same year the Des Moines office handled 89,507,072 outgoing letters and circulars, 4,954,287 pieces of parcel post, and $34,133,622$ pounds of second class matter, all printed in Des Moines. ${ }^{25}$

The following figures indicate the tremendous increase in Des Moines' postal business in the past fifty years:

\begin{tabular}{|c|c|c|}
\hline Fiscal $Y e$ & ear & Fross Receipts \\
\hline 1880. & $\ldots$ & $. \$ \quad 47,406.81$ \\
\hline 1885 & & $93,308.83$ \\
\hline 1890 & & $124,381.87$ \\
\hline 1895 & & $184,904.79$ \\
\hline 1900 & & $294,938.43$ \\
\hline 1905 & & $467,361.73$ \\
\hline 1910 & & $764,067.37$ \\
\hline 1915 & & $1,119,932.90$ \\
\hline $1920 \ldots$ & & $2,008,808.07$ \\
\hline 1925 & & $2,874,780.82$ \\
\hline 1930 & & $3,609,129.55^{26}$ \\
\hline
\end{tabular}

25 Des Moines Tribune, January 28, 1328.

23From figures furnished by the Auditor for the Post Office Department at Washington, D. C., and: by Mr. John Ryan of Des. Moines. 
The year 1930 was a banner one for the Des Moines post office in many respects :

1. The total receipts for that year were the largest to date.

2. Seven months of that year showed receipts exceeding $\$ 300,000$.

3. Every month showed an increase over the corresponding month of the preceding year.

4. The best previous monthly total of receipts $(\$ 332,169.63$ in March, 1929) was broken twice--in December $(\$ 364,-$ $960.88)$ and in March $(\$ 366,020.31)$.

5. Des Moines led all the larger cities of the country in per centage of gain in three different months.

6. Des Moines was the lowest of forty-five larger cities in per centage of clerk hire to receipts.

7. Des Moines was the lowest in the same group in per centage of city delivery cost to receipts. ${ }^{2 \pi}$

Since 1930 , receipts have declined considerably, amounting to $\$ 2,523,711.02$ for the fiscal year ending June 30,1933 ; probably increased postal rates and the depression account for this decrease. It is almost certainly true that when general business conditions improve, the Des Moines post office will again show a corresponding improvement.

\section{READY MADE CLOTHING}

The subscriber has just received from New York a large assortment of clothing, consisting in part of blue, black, brown and olive dress and frock coats; blue, black, brown and fancy colored pants; brown linen and gloss frock coats and roundabouts; Irish linen shirts, white and brown linen pantaloons; black, blue, velvet and fancy vests, for sale by E. Lockwood. Advertisement in the (Dubuque) Iowa News, July 15, 1837. (In the Newspaper Division of the Historical, Memorial and Art Department of Iowa.)

27Des Moines Tribune, July 1, 1930, and February 5, 1931. 
Copyright of Annals of Iowa is the property of State of Iowa, by \& through the State Historical Society of Iowa and its content may not be copied or emailed to multiple sites or posted to a listserv without the copyright holder's express written permission. However, users may print, download, or email articles for individual use. 